Cornell University Law School Scholarship@Cornell Law: A Digital Repository

$3-1994$

\title{
Laws Intentionally Favoring Mainstream Religions: An Unhelpful Comparison to Race
}

Gary J. Simson

Cornell Law School, simson@law.mail.cornell.edu

Follow this and additional works at: https://scholarship.law.cornell.edu/facpub

Part of the Civil Rights and Discrimination Commons, Constitutional Law Commons, First Amendment Commons, and the Religion Law Commons

\section{Recommended Citation}

Simson, Gary J., "Laws Intentionally Favoring Mainstream Religions: An Unhelpful Comparison to Race" (1994). Cornell Law Faculty Publications. 1637.

https://scholarship.law.cornell.edu/facpub/1637

This Article is brought to you for free and open access by the Faculty Scholarship at Scholarship@Cornell Law: A Digital Repository. It has been accepted for inclusion in Cornell Law Faculty Publications by an authorized administrator of Scholarship@Cornell Law: A Digital Repository. For more information, please contact jmp8@cornell.edu. 


\title{
LAWS INTENTIONALLY FAVORING MAINSTREAM RELIGIONS: AN UNHELPFUL COMPARISON TO RACE
}

\author{
Gary J. Simson†
}

In various articles spanning the past thirty years, Jesse Choper has argued for a rather indulgent approach to laws adopted to favor one or more religions. ${ }^{1}$ According to Choper, intentional government preferences for religion should survive Establishment Clause review as long as they are not likely to "impair religious freedom,"2 by which he means not likely to make people either (1) act contrary to their religion, (2) engage in a religious activity that, though not barred by their religion, they would not otherwise have engaged in, or (3) contribute financial support to religion. ${ }^{3}$

Applying this approach, Choper has, for example, argued that the Supreme Court erred in striking down a Kentucky statute that required public schools to post the Ten Commandments in all classrooms ${ }^{4}$ and an Arkansas statute that prohibited public schools from teaching evolution. ${ }^{5} \mathrm{He}$ also has made clear that, as long as the costs to the government are relatively minimal, he has no difficulty with the government's putting up crèches or other religious holiday displays. ${ }^{6}$

$\dagger$ Professor of Law, Cornell Law School. B.A. 1971, J.D. 1974, Yale University. I am grateful to Kathy Abrams, Rosalind Simson, and Mark Solomon for various helpful comments.

This article is a slightly revised version of remarks delivered as a response to Professor Choper's Stevens Lecture. As in my oral remarks, I will not attempt here to comment on the full range of issues addressed by Professor Choper, but instead will focus on the major theme that seems to me most problematic.

1 See, e.g., Jesse H. Choper, Church, State and the Supreme Court: Current Controversy, 29 ARIz. L. REv. 551 (1987) [hereinafter Choper, Current Controversy]; Jesse H. Choper, The Religion Clauses of the First Amendment: Reconciling the Conflict, 41 U. Prrr. L. REv. 673 (1980) [hereinafter Choper, Reconciling the Conflict]; Jesse H. Choper, Religion in the Public Schools: A Proposed Constitutional Standard, 47 MinN. L. Rev. 329 (1963).

2 See Choper, Reconciling the Conflict, supra note 1, at 675.

3 See id.

4 See Choper, Current Controversy, supra note 1, at 554 (discussing Stone v. Graham, 449 U.S. 39 (1980)).

5 See Choper, Reconciling the Conflict, supra note 1, at 687-88 (discussing Epperson v. Arkansas, 393 U.S. 97 (1968)).

6 See Choper, Current Controversy, supra note 1, at 553-54. With regard to the Supreme Court's approach to such issues, see Allegheny County v. ACLU, 492 U.S. 573 (1989) (invalidating the display in a county courthouse of a crèche standing alone, while upholding the display outside a local government building of a giant Hanukkah menorah alongside a Christmas tree); Lynch v. Donnelly, 465 U.S. 668 (1984) (upholding the display of a crèche 
In addressing the constitutionality under the Establishment Clause of these different forms of government action, Choper has readily conceded that the purpose underlying each is solely religious ${ }^{7}$ - a concession that, without more, would require their invalidation under the Supreme Court's basic approach to Establishment Clause problems since at least 1963.8 Choper has maintained, however, that these government actions do not overstep constitutional bounds because they are not, in his judgment, likely to impair religious liberty.

In light of Choper's prior writings, it hardly comes as a surprise to find him arguing in the lead article to this symposium for relatively relaxed judicial review of laws deliberately advantaging mainstream religions.9 The defense that Choper offers here for his position, however, is novel: a defense predicated on differences that he perceives between laws intentionally favoring mainstream religions and ones intentionally favoring the racial majority. According to Choper, "there are significant differences between race and religion when deliberate advantage is at issue. These distinctions are sufficient to warrant contrasting constitutional treatment." 10

I hope to demonstrate in this article the unpersuasiveness of this defense. Before turning to the particulars of the defense, however, I probably, in the interest of candor, should make clear the basic skepticism with which I approach it. Much as I admire Choper's willingness to stand by a position that he deems correct in the face of substantial Supreme Court precedent to the contrary, nothing that he has said to date persuades me that his position merits adoption. In my view, he

as part of a city's annual Christmas display, which also consisted of, among other things, a Santa Claus house, reindeer, and cut-out figures of a teddy bear and clown).

7 See supra notes 4-6.

8 In Abington School Dist. v. Schempp, 374 U.S. 203, 222 (1963), the Court announced a two-part test for constitutionality under the Establishment Clause, and one part was that "there must be a secular legislative purpose." The Court in Lemon v. Kurtzman, 403 U.S. 602, 612-13 (1971), added a third requirement to the Schempp test without altering the original two. Although the Court has not been entirely consistent in its explanations of the secular purpose requirement, it seems clear that the Court will not strike down a law for failure to meet this requirement unless the law is proven to rest exclusively or almost exclusively on religious purposes. See Gary J. Simson, The Establishment Clause in the Supreme Court: Rethinking the Court's Approach, 72 CORNELl L. Rev. 905, 909 \& n.24 (1987).

9 Choper devotes little attention in this article to laws deliberately advantaging minority religions because he regards it as largely noncontroversial that such laws should receive relatively relaxed review. See Jesse H. Choper, Religion and Race Under the Constitution: Similarities and Differences, 79 CoRnel. L. REv. 491, 504-05 (1994). I would apply the same rigorous review to laws intentionally favoring minority religions as I would apply to ones intentionally favoring mainstream religions. See Simson, supra note 8. I agree, however, that laws intentionally favoring minority religions tend to be less problematic than ones intentionally favoring mainstream religions, because they more commonly take the form of exemptions from generally applicable laws that, if applied to those exempted, would impose a substantial burden on religious liberty.

10 Choper, supra note 9, at 501. 
assigns far too little importance to government sponsorship of religion-one of the principal evils that, according to the Supreme Court ${ }^{11}$ and many commentators, ${ }^{12}$ the Establishment Clause was intended to provide protection against. ${ }^{13} \mathrm{I}$ also believe that he fails to appreciate the special threat posed by laws intentionally advantaging religion as "step[s] that could lead" 14 to the ultimate evil of a governmentally established religion. Indeed, not only do I agree with the Supreme Court that laws based solely on a purpose of favoring religion should, without more, be struck down; I also believe that any law that would not have been adopted but for a religious purpose should be struck down, whether or not that purpose was exclusive or even primary. ${ }^{15}$

11 See Lemon, 403 U.S. at 612.

12 See, e.g., Arnold H. Loewy, Rethinking Government Neutrality Towards Religion Under the Establishment Clause: The Untapped Potential of Justice O'Connor's Insight, 64 N.C. L. REv. 1049 (1986); William P. Marshall, "We Know It When We See It": The Supreme Court and Establishment, 59 S. CAL. L. REv. 495 (1986); Simson, supra note 8; William Van Alstyne, Trends in the Supreme Court: Mr. Jefferson's Crumbling Wall-A Comment on Lynch v. Donnelly, 1984 Duke L.J. 770.

13 As indicated by Choper's discussion here of government financial support of religion, as well as by his characterization elsewhere of such support as an impairment of religious freedom, he expressly assigns much more significance to this commonly cited Establishment Clause evil than he does to sponsorship. See Choper, supra note 9, at 512-13; supra notes 2-3 and accompanying text. His treatment of parochial school aid, however, suggests that, as a practical matter, the difference in his express approaches to sponsorship and financial support of religion generally may be of little consequence. See Jesse H. Choper, The Establishment Clause and Aid to Parochial Schools, 56 CAL. L. REv. 260 (1968) (aid to parochial schools should not be regarded as government financial support of religion as long as the amount awarded does not exceed the value of the secular services provided by the schools). See also Choper, Reconciling the Conflict, supra note 1, at 679-80 (acknowledging in 1980 that under his approach to parochial school aid "all of the many aid programs to elementary and secondary parochial schools that the Court has invalidated since 1971 would have probably survived constitutional challenge"). For Establishment Clause analyses much less permissive of parochial school aid, see Paul A. Freund, Public Aid to Parochial Schools, 82 HARV. L. REV. 1680 (1969); Simson, supra note 8.

14 Lemon, 403 U.S. at 612.

15 See Simson, supra note 8, at 908-11. See also id. at 922-23 (suggesting that the effects prong of the Lemon test is best understood as a means of weeding out laws that there is good reason to suspect are based on a religious purpose). As discussed in id. at 913-15, I believe that certain "religious" purposes do not provide a basis for invalidation under the Establishment Clause because of their relationship to the requirements of the First Amendment's Free Exercise Clause. Moreover, I should note in this regard that I believe that the Free Exercise Clause is properly interpreted to require rigorous review of substantial burdens on religious exercise that result from generally applicable laws. Though contrary to Employment Division v. Smith, 494 U.S. 872 (1990), this view is in keeping with the Supreme Court's basic approach prior to Smith. See, e.g., United States v. Lee, 455 U.S. 252, 257-58 (1982); Wisconsin v. Yoder, 406 U.S. 205, 215 (1972). It is also in keeping with the Religious Freedom Restoration Act of 1993, which was enacted essentially to override Smith. See Pub. L. No. 103-141, 107 Stat. 1488 (to be codified at 42 U.S.C. $\S \S 2000$ bb to $2000 \mathrm{bb}-4)$. 
Choper's argument in this symposium for rather relaxed review of laws intentionally favoring mainstream religions essentially consists of three steps:

1. Laws deliberately disadvantaging religious minorities are as disrespectful of religious minorities as laws deliberately disadvantaging racial minorities are of racial minorities. Courts therefore should treat both types of laws the same, reviewing them with the suspicion and "strict scrutiny" that laws treating people with such tangible disrespect so obviously demand.

2. Laws deliberately favoring the racial majority are as disrespectful of racial minorities as laws deliberately disadvantaging racial minorities and therefore deserve the same highly demanding level of judicial review.

3. Laws deliberately favoring mainstream religions are plainly not as disrespectful of religious minorities as laws deliberately favoring the racial majority are of racial minorities. Courts therefore should take a considerably more indulgent approach to laws deliberately favoring mainstream religions than the strict scrutiny approach that laws favoring the racial majority are most sensibly understood to require. ${ }^{16}$

I believe that this argument rests, implicitly or explicitly, on three questionable assumptions that, taken together, deprive the argument of any significant force.

16 As I have indicated, Choper compares laws favoring the racial majority with ones favoring mainstream religions. In the lecture upon which his article is based, he explained that he made the comparison to mainstream religions rather than to the majority religion because in the United States "there is no majority religion." Text of Stevens Lecture at p. 5. One consequence of making the comparison as he does is that he implicitly and, I think, anomalously treats Judaism-a religion shared by less than three percent of the United States population, see AMErican Jewish Committee, AMerican Jewish YeAR Book 1992, at 144 (1992) - as somehow on a par in terms of societal dominance or "in"-ness with the racial majority. See Choper, supra note 9, at $501 \mathrm{n.76}$ (characterizing Judaism as a mainstream religion).

In my view, drawing the comparison to "mainstream religions" needlessly confuses the issue. First of all, it is not clear that there is no majority religion in the United States. Although it is undoubtedly inappropriate for certain purposes to speak of Christianity as a single religion, I question whether it is inappropriate to speak of Christianity in this way for purposes of the present discussion. As exemplified perhaps most clearly by controversies over crèches funded by the government or on government property, it is not uncommon for laws favoring religion to endorse religious beliefs shared across the divisions of Christianity.

Second and more basically, rather than draw the comparison to mainstream religions or the majority religion, Choper most logically and easily could draw it to majoritarian religious beliefs. Whether or not it is appropriate in this context to speak of Christianity as the majority religion, there plainly are majoritarian religious beliefs in the United Statesones that run through various, if not all, divisions of Christianity as well as, at times, Judaism and other religions. 
Assumption A: The special concern under the Equal Protection Clause with laws deliberately disadvantaging racial minorities is based on the degree of disrespect communicated by such laws.

Though questionable, this assumption is substantially more defensible than the other two that I will examine. For that reason, and because a full-scale examination of the validity of the assumption would take me far afield for present purposes, I am content for now simply to highlight that the assumption is open to reasonable debate.

The history of the adoption of the Equal Protection Clause indicates quite clearly that its framers viewed laws deliberately disadvantaging blacks with special concern. ${ }^{17}$ Not nearly as clear, however, is what feature or features of these laws gave rise to this special concern-a question of vital importance to determining the extent, if any, to which this special concern should (for purposes of interpreting the Equal Protection Clause) be understood as extending beyond racial classifications to classifications of other sorts. At least implicitly, Choper's answer to this question is that the framers' special concern with laws deliberately disadvantaging blacks was rooted in the gross disrespect that such laws show to blacks.

Choper is not alone in offering this answer, ${ }^{18}$ but various people have suggested, expressly or implicitly, that the question should be answered quite differently. Some have suggested, for example, that the special concern with racial classifications reflected in substantial part an objection to disadvantaging people on the basis of an unchangeable characteristic, ${ }^{19}$ while others have taken the view that this concern was prompted solely by the distinctive history of racial discrimination in the United States. ${ }^{20}$ As indicated elsewhere, ${ }^{21}$ my own view is that the special concern with racial classifications was grounded in suspicion of the fairness and objectivity of the legislative process-a process dominated by whites not only in terms of actual representation on legislatures but also in terms of capacity to influence lawmaking bodies. The Supreme Court has not spoken clearly with regard to the source or sources of this special concern, seemingly suggesting

17 See McLaughlin v. Florida, 379 U.S. 184, 191-92 (1964); Strauder v. West Virginia, 100 U.S. 303, 306 (1880).

18 See, e.g., Charles L. Black, Jr., The Lawfulness of the Segregation Decisions, 69 YALE L.J. 421 (1960).

19 See, e.g., Samuel T. Perkins \& Arthur J. Silverstein, Note, The Legality of Homosexual Marriage, 82 YALE L.J. 573, 576 (1973).

20 See, e.g., Sugarman v. Dougall, 413 U.S. 634, $649-50$ (1973) (Rehnquist, J., dissenting).

21 Gary J. Simson, Note, Mental Illness: A Suspect Classification?, 83 YALE L.J. 1237 (1974). 
different answers at different times. ${ }^{22}$ In short, without canvassing further the range of answers offered, it should be apparent that Choper's answer, though not patently ill-founded, is hardly noncontroversial.

Assumption B: Laws deliberately favoring mainstream religions are plainly not as disrespectful of religious minorities as laws deliberately favoring the racial majority are of racial minorities.

In effect, the principal support that Choper offers for this assumption is his intuitive judgment, but he also appears to offer two somewhat distinct arguments. First, the religious beliefs deliberately favored by law tend to be so "appealing" or "wholesome" that nonadherents of the favored religion often do not regard laws deliberately favoring religion as communicating to them any sort of message of disrespect. ${ }^{23}$ Second, "our heritage" affirms that religion is such an inherently good thing that it is illogical to think that intentional government favoring of religion could take on for nonadherents of the favored religion anything approximating the type of ugly visage that intentional government favoring of the racial majority no doubt takes on for racial minorities. ${ }^{24}$

As an initial matter, I at least would like to raise the question of whether courts should be willing to act on the type of qualitative judgment made by Assumption B absent some empirical support for the judgment made. Assuming, however, that that objection is not dispositive, I would argue that if, as Choper at least implicitly suggests, intuitive judgment is the key, his intuition is simply wrong. From my perspective, the two sets of laws at issue generally seem about equally effective at communicating disrespect. Indeed, given Choper's recognition at the start of his article that race and religious belief "have been the object of public (and private) stereotyping, stigma, subordination, and persecution in strikingly similar ways," 25 I have some difficulty understanding why his intuition on this matter is as different from mine as it is.

I think the explanation lies in the two arguments that I identify above as offered in support of his judgment-arguments that I find fundamentally and similarly flawed. For so many people, and I include myself in the group, religion is a source of many good thingsinsight, guidance, inspiration, comfort, and more. As a result of these

22 See, e.g., Cleburne v. Cleburne Living Center, Inc., 473 U.S. 432, 440 (1985); Plyler v. Doe, 457 U.S. 202, $216-17$ n.14 (1982); McLaughlin v. Florida, 379 U.S. 184, 191-92 (1964).

23 See Choper, supra note 9, at 502.

24 See id. It is not entirely clear whether in making these two arguments Choper is discussing nonadherents' actual perceptions or, instead, the perceptions that nonadherents most reasonably would have. My rendition of the arguments assumes the former, but my criticisms are essentially the same regardless.

25 Id. at 492. 
many positive associations, however, it is very easy and natural to underestimate the harmful effects that religion can have when the hand of the state is placed behind it. Choper's two arguments for Assumption B seem to epitomize this mindset. He is so focused on the positive aspects of religion that he fails to take seriously how effective government sponsorship of religion can be at inflicting a feeling of second-class citizenship on people who adhere either to religions other than the favored one or to no religion at all. However benevolent the government's motives may be, its putting its stamp of approval on a particular religion or religious belief communicates to nonadherents a message of very basic disrespect-a message that they are less than full members of the political community. ${ }^{26}$ I can not say for certain that this message is every bit as disrespectful as the message sent to racial minorities by laws intentionally favoring the racial majority. I am confident, however, that any difference is much less pronounced than Choper suggests.

Assumption C: The fact that laws deliberately favoring mainstream religions are plainly not as disrespectful of religious minorities as laws deliberately favoring the racial majority are of racial minorities indicates that courts should review laws of the former type with much less rigor than laws of the latter variety.

Even assuming, for purposes of argument, that Assumptions A and $B$ are valid, Assumption $C$ almost certainly is not. Its primary defect is that it fails to take account of the fact that the principal constitutional objection to laws deliberately favoring the racial majority is based on the Equal Protection Clause while the principal constitutional objection to laws deliberately favoring mainstream religions is based on the Establishment Clause. In interpreting different constitutional provisions, courts sensibly recognize that different provisions reflect different concerns and tailor their approach to each provision to the particular concerns that prompted its adoption. Even if one assumes that the intensity of review under the Equal Protection Clause should vary according to the degree of disrespect communicated by the law under review, it does not follow that the intensity of review under the Establishment Clause should vary according to how the law under review compares in degree of disrespect communicated to laws given the most intense equal protection review. It would only follow if the Establishment Clause is as fully rooted as the Equal Protection Clause in a concern for the disrespect communicated by laws, and by all indications, it is not.

26 See Allegheny County v. ACLU, 492 U.S. 573, 592-94 (1989); Lynch v. Donnelly, 465 U.S. 668, 687-88 (1984) (O'Connor, J., concurring); Simson, supra note 8, at 916; Van Alstyne, supra note 12 , at $782,787$. 
The language ${ }^{27}$ and history ${ }^{28}$ of the Establishment Clause underline its framers' concern with laws that threaten to lead a step at a time to an established religion and to all the persecution and intolerance that such establishments typically entailed. Although the clause may be partly rooted in a concern for the disrespect communicated to nonadherents of a favored religion, the evils at which it took aim in order to avoid movement toward the ultimate evil of an established religion were considerably broader than that. As the Supreme Court succinctly and, I believe, accurately described them, these evils primarily include "sponsorship, financial support, and active involvement of the sovereign in religious activity." 29 In keeping with this understanding of the clause's roots, the intensity of judicial review under the clause should vary not according to the degree of disrespect communicated by the law under review, but instead according to the extent to which the law implicates any of the three evils identified by the Court. ${ }^{30}$

27 See U.S. Const. amend. I ("Congress shall make no law respecting an establishment of religion") (emphasis added); Lemon v. Kurtzman, 403 U.S. 602, 612 (1971).

28 See, e.g., Everson v. Board of Educ., 330 U.S. 1 (1947); Edmond Cahn, The "Establishment of Religion" Puzzle, 36 N.Y.U. L. REv. 1274 (1961); Van Alstyne, supra note 12.

29 Walz v. Tax Comm'n, 397 U.S. 664, 668 (1970). See also Lemon, 403 U.S. at 612 (quoting Walz).

30 See Simson, supra note 8, at 911, 915-16. 